\title{
Innovation Challenges of Village-owned Enterprises
}

\author{
Gabriella Hanny Kusuma ${ }^{1}$, P. Didit Krisnadewara ${ }^{2}$ \\ ${ }^{1}$ Universitas Atma Jaya Yogyakarta \\ ${ }^{2}$ Universitas Atma Jaya Yogyakarta \\ Hanny.kusuma@gmail.com
}

\begin{abstract}
The research intended to explore the innovation challenge of village-owned enterprises. The challenge focus on managerial and innovation capabilities of village owned enterprises. This study uses a Community-Based Research (CBR). This approach is used to find out how far from the community at the micro, mezzo, and macro level that can help the village as a whole. To collect the data, this research used observation, personal in-depth interview, and focus group discussion. The village-owned enterprises need innovation for their sustainability. This research found 3 major challenges for the village-owned enterprises innovation. The challenges are a) Lack of Knowledge and skills, b) Financial and infrastructure limitation, c) Social - professional conflict. Human factor is the main challenge that needs to be solved by village-owned enterprises. The village-owned enterprises should overcome these challenges hence they can be spared from Innovation myopia. This research conducted in the village-owned enterprises which dominated by Javanese culture. This research also conducted in the service sector. In the future, exploring innovation challenge in the village-owned enterprise which has different culture would be interesting. The future research also can explore innovation challenge in the manufacturer village-owned enterprises. This paper shows the innovation challenge in village-owned enterprises which has unique characteristic.

Keywords: Badan Usaha Milik Desa, Bumdes, innovation challenges, sustainability, village-owned enterprises
\end{abstract}

JEL $\quad:$ M11, M14

DOI $\quad: 10.24002 /$ kinerja.v22i1.2130

Received : $1 / 8 / 2019$

Reviewed: $2 / 6 / 2019$

Final Version: 3/25/2019 


\section{INTRODUCTION}

Development is the process by which members of a community as individually to increase capacity and institutions to generate sustainable improvements and uneven in quality of life according to their own aspirations (Korten, 1993). Over the last 40 years, the Indonesian government has made various programs to alleviate poverty through regional, institutional, strategies and specific development policies (Prabowo, 2014). According to the draft of Law on Village that currently has been passed into Law No. 6/2014 on Village maintains the status of village as the object of development in its implementation. Indonesia has 74,093 villages, where more than 32 thousand villages fall into the category of underdeveloped villages (CBS, 2013).

Village is a unit of traditional society (Nurcholis, 2011). In Indonesia context, village is a subject of development. It means that village acts as the main actor (subject) that plan, fund and implement the development (Afifah et al., 2017). In order to support the village survival, the village has resources arranged in accordance with its institutional system (Afifah et al., 2017).

One of the most important solutions for sustainable rural development is village entrepreneurship development (Ansari, 2013). Entrepreneurship is one of the activities which can resolve many major challenges (such as unemployment, low income, lack of economic diversity and etc.) in village and also has positive impacts on other aspects of human life (Faraji et al., 2011). In social regard, entrepreneurship has positive impacts and benefits such as: creates employment and reduces social stresses; and also provides resources exploitation and their activation for productivity (Ansari, 2013).

Entrepreneurship is the major force of economic development in village and is along with change, innovation and production services (Markley, 2005). An entrepreneurship activity with high effectiveness leads to economic development (including employment creation, innovation activities and competitiveness) (Verheul et al., 2001) and poverty alleviation. Village-owned enterprise have significant contribution to poverty alleviation trough "social business activities" in the community, therefore it needs to be empowered (Prabowo, 2014).

A major issue related to the Village-owned enterprise is the sustainability (Ansari, 2013). Barriers of Village-owned enterprise sustainability based on some research related to low level of skills, lack of financial resources, lack of information and knowledge about entrepreneurship (Eftekhari and Hamdolah, 2011), uncertainty and ambiguity in the proceeds from entrepreneurship, the risk of losing all applied capitals, and persistence in the process (Fadaie et al., 2010).

Dynamic and multidimensional nature inherent in the ways of poverty requires a more comprehensive management and extensive study of the experiences of individual-collective at the community and at the local/regional level (Prabowo, 
2014). Therefore, exploration on situation and interpretation related to sustainability of Village-owned enterprise are needed.

Village-owned enterprises need competitive advantage to survive in the long term, and innovation is one of the key drivers of sustainable competitive advantage (Brines, Shepherd, \& Woods, 2013). Innovation is capability that allows Villageowned enterprises to integrate, build, and reconfigure internal and external competences to address rapidly changing competitive environments (Saunila \& Ukko, 2014).

Since many village-owned enterprises can be clasified as SMEs, it seems appropriate to also have a study on innovation in village-owned enterprises. It is relevant due to its constraint on resources scarcity (Indarti \& Langenberg, 2004). Innovation is critical for the sustainable success of village-owned enterprises yet we still have limited understanding of what promotes and/or constrains on innovative activities (Brines, et al., 2013).

Based on the explanation above, this research intended to explore and analyze the innovation challenge on village-owned enterprises operation related to their sustainability.

\section{LITERATURE REVIEW}

The Resource Based View (RBV) and Stakeholder theory are used in this research to frame the phenomenon of village-owned Enterprises which are the object of the research. Whereas to support the two main theories, this research also refers to the thesis on the Village, the Village of Entrepreneurship, and the VillageOwned Enterprises (BUMDes).

\subsection{Village-Owned Enterprises}

Based on Indonesian constitution about village No.6 in 2014, definition of the village is a legal community unit that has territorial boundaries. It has authorization to regulate and manage government affairs, the interests of the local community based on community initiatives, the rights of origin, and / or traditional rights which are recognized and respected in the government system of the Republic of Indonesia (NKRI). As a representative of the state, the village is obliged to carry out development, both physical development and human resource development, as an effort to improve the quality of life and life for the greatest welfare of the village community. Village also define as a unit of traditional society which has political, economic, judicial, socio-cultural and security and defense institutions that develops itself to fulfill its needs" Nurcholis (2011).

In order to support the village survival, the village has resources arranged in accordance with its institutional system. Therefore, village has the right to arrange and manage local affairs based on the village origin; it is known as village autonomy 
(Afifah, 2017). This sustainable village development should not damage the environment and gives sovereign rights to regulate itself (Susetiawan, 2011).

Village communities must be empowered so that development able to reaches its goals. Hence, it is important to empower rural communities to build the communities by encouraging, motivating, and developing the potential of local resources they have (Prabowo, 2014). Empowering the community can be done by implement these two approaches: (a) Community needs in making changes and preventing undesirable things; and (b) Political will and the ability of the village government with the community in implementing the development plans that have been prepared (Rustiadi 2001 cited in Bachrein, 2010).

One important solution for empowering communities is entrepreneurship for village communities. Entrepreneurship is considered as a mechanism which provides the optimal allocation of resources by recognizing the strengths and future opportunities along with weaknesses and threats in rural areas (Heaton, 2005). Village-owned enterprises support this solution. Village-owned enterprise have significant contribution to poverty alleviation trough "social business activities" in the community (Prabowo, 2014).

The establishment of a Village-Owned Enterprise is based on Law Number 32 of 2004 concerning Regional Government Article 213 paragraph (1) stated that "The village can establish a village-owned business entity in accordance with the needs and potential of the village". The establishment of Village-owned enterprises aims to explore and optimize the entrepreneurial potential of the village (Prabowo, 2014).

Village-owned enterprises become a strategy in the development and elevation of community welfare. Resources and facilities are provided spontaneously by village communities to lead to changes in village socio-economic conditions (Ansari et al., 2013). Village-owned enterprises give social benefits to the society through state which represents a kind of socio-economic development of the community. Whatever community participation in entrepreneurial activities is higher, achieving socio-economic development is faster (Behkish, 2002).

Village community should overcome many barriers to ensure the sustainability of entrepreneurial village. The barriers are 1) a culture that is not able to support entrepreneurship, 2) long distance between market and services, 3) gap in access to capital, 4) reduction in network and communication opportunities and 5) lack of industrial clusters to accelerate innovation (Markley, 2002)..

\subsection{Stakeholders}

Stakeholders are individuals or groups that can influence the achievement of the goals of the organization, or parties affected by the achievement of organizational goals (Freeman et al., 1983 in Mitchell et al., 1997). Stakeholders have several attributes, namely: power, legitimacy, and urgency. The description of stakeholder attributes can be seen in Table 1. 
Stakeholder theory focuses on who holds power, legitimacy, and has urgency in the organization (Mitchell et al., 2011). In the context of this research, it refers to who holds power and legitimacy, has specific interests and roles in village dynamics, controls knowledge and resources, and has an interest in the economic development of the village.

Table 1. Identification of Stakeholders

\begin{tabular}{|c|c|c|}
\hline Attributes & Definition & Basic \\
\hline Power & $\begin{array}{l}\text { Relationships between actors where } \\
\text { one actor can ask other actors to do } \\
\text { something without being denied }\end{array}$ & $\begin{array}{l}\text { - Coercion: Strength / threat } \\
\text { - } \quad \text { Benefits: material incentives } \\
\text { - } \quad \text { Normative: symbolic influence }\end{array}$ \\
\hline Legitimacy & $\begin{array}{l}\text { General perceptions or assumptions } \\
\text { about one's actions are appropriate, } \\
\text { expected, and appropriate according } \\
\text { to the system, norms, values, beliefs }\end{array}$ & $\begin{array}{ll}\text { - } & \text { Individual } \\
\text { - } & \text { Organization } \\
\text { - Social }\end{array}$ \\
\hline Urgency & $\begin{array}{l}\text { Levels where stakeholders can ask to } \\
\text { be noticed. }\end{array}$ & $\begin{array}{l}\text { - Time sensitivity: degree of delay } \\
\text { in which claims or relationships } \\
\text { cannot be accepted by } \\
\text { stakeholders } \\
\text { - Critical/urgent: } \\
\text { The importance of claims or } \\
\text { relationships from stakeholders }\end{array}$ \\
\hline
\end{tabular}

Source: Mitchell et al., 1997

\subsection{Village-Owned Enterprise's Resources}

To build an independent village, income sources for the village from the village itself is needed. Business units that move in the village must have distinctive features and competitive advantages so that they can make a significant contribution to improving the welfare of rural communities

Competitive advantage is determined by social capital, human capital, and financial capital (De Massis et al., 2015). Social capital is related to relationships between people in the organization (internal social capital) and between organizations and outsiders (external social capital).

According to the World Bank (1998), social capital is a society that includes institutions, relationships, attitudes and values that govern interactions among people and contribute to economic and social development. In Social Capital, there needs to be shared values and organizing roles expressed in personal relationships, trust, and common sense of shared responsibility; so that society becomes more than just a collection of individuals.

Human capital is defined as knowledge and skills inherent in people (Hatch et al., 2004 in De Massis et al., 2015). Human capital can be associated with high dedication and commitment (Cabrera-Suarez et al., 2001), motivation (1988), and 
high personal relations (Trevinyo-Rodriguez et al., 2006). Human Capital has been a crucial issue related to sustainability of village-owned enterprises because the barriers for doing sustainable entrepreneurship in rural areas are 1) low level of skills, 2) lack of financial resources, 3) lack of information and knowledge (Eftekhari and Hamdolah, 2011).

Knowledge is defined as the integration of information, ideas, experience, intuition, skill and lessons learned that creates added value for a firm (Dana, et al., 2005). Skill is the ability to carry out a particular task or activity, especially because it has been practices. Pure knowledge is the information behind that skill (Chirico, 2008; Nonaka \& Takeuchi, 1995). The knowledge takes two forms, tacit and explicit. It raises a dilemma for companies, referred to as the paradox of tacit and explicit knowledge. These dilemmas have lead to idiosyncratic knowledge, or the combination of tacit and explicit knowledge (Jassimuddin, et al., 2005).

Knowledge is fuel for the innovation. Innovation is needed for village-owned enterprises' sustainability. Innovativeness is an important entrepreneurial capability that village-owned enterprises can use to achieve competitive advantage (Llach \& Nordqvist, 2010). One of the most important factors for generating innovations is the knowledge basis of the workforce. It can represent a competitive advantage when the village-owned enterprises is able to develop, keep, and exchange the knowledge as it is based at least partially on experience (Cabrera-Suarez, et al., 2001; Werner, et al., 2017; Chirico, 2008).

Village-owned enterprises also need entrepreneurial skills. Four groups of skills required by village-owned enterprises are emphasized: 1) Scientific and technical skills based on the type of industrial activity, 2) Management skills including: Financial management, marketing, administrative and personnel affairs, 3) Entrepreneurial skills including: Ability to recognize and use of new opportunities in the market and provide innovative solutions to deal with challenges. 4) Personnel skills including: Self-reliance, self-confidence, creativity, responsibility (Ansari, 2013).

\section{METHODOLOGY}

This study uses a Community-Based Research (CBR). This approach is used to find out how far from the community at the micro, mezzo, and macro level that can help the village as a whole, and also assess the direction and independence of the economy. To get the right data and information, the data is done by:

1. Observing village conditions directly and studying village-owned enterprises documents that become secondary data. Data collection done by observing village-owned enterprises daily activities and also documents owned by the management. 
2. Personal in-depth interviews with village key stakeholders, namely village chief, village officials, managers of village-owned enterprises, activists of community groups, community leaders, and business people in the village. Personal interviews are conducted on a minimum of 15 key stakeholders and aim to explore basic information about the existence of village-owned enterprises as one of the village economic drivers.

3. The focus group discussion will conduct with representatives of each member of the community group and village institutions such as PKK (Women community), Farmer group (Gapoktan), village-owned enterprises managers, youth groups, joint business groups (KUB) as an effort to cross check the information obtained from the previous data collection steps.

This study uses a Community Based Research approach conducted qualitatively. In general, data analysis strategies in qualitative research are: 1) Putting information on a different arrangement; 2) Create a matrix or category and place evidence in that category; 3) Make a data display; 4) Make tabulations of different events; 5) testing the complexity of the tabulations made; and 6) compile information in chronological order (Miles and Huberman, 1992).

The initial stage of the data analysis process is to create a database to store copies of information provided by participants (Wahyuni, 2012). Following the recommendations of Bryman and Bell (2007) cited in Chirico (2008), this research uses each data source and each participant as a tool to check each other. The use of two participants in each organization allows for a comparison of the answers given by them. The use of other data sources (secondary data) allows further confirmation of information provided by participants (Chirico, 2008). The description of each case is prepared independently.

This study uses content analysis to answer research questions. Content analysis is defined as a research method for subjective interpretation of data content through a systematic classification process of coding and identifying themes or patterns (Wahyuni, 2012). This method summarizes and classifies large amounts of data into categories that represent the same meaning (Weber, 1990 cited in Wahyuni, 2012).

The results of the analysis were processed using the visual map and temporal bracketing strategy (Langley, 1999). The visual map strategy allows displaying large amounts of data, and is easily used to display symptoms, parallel processes, and the passage of time. This strategy is an intermediary strategy to develop a more abstract concept using the temporal bracketing strategy. The temporal bracketing strategy transforms the formless data into several sequential but interconnected parts. In each phase, data is used to describe the process according to the pattern. This strategy is suitable for analyzing dynamic processes in organizations. This strategy accommodates data as a whole which concerns events, relations, interactions, feelings, cognitions, etc. (Langley, 1999). 
To ensure validity and credibility, this study uses several methods, namely the validation of respondents (member checking) and triangulation (Yin, 2009; Creswell, 2010; Wahyuni, 2012). Triangulation used in this research is source triangulation.

Source triangulation is done by obtaining information from several sources to minimize and understand the biases that arise from people with different roles (Yin, 2009; Creswell, 2010; Wahyuni, 2012). In this study, information sources were obtained from multiple parties. Sources of supporting evidence such as organizational documents, archives, websites, and articles in the mass media also support the triangulation of sources in this study.

Validation with member checking involves participants in the validation process. The results of the research were sent to participants to ensure the results of the study were in accordance with the perspectives and experiences of the participants. This process is also to ensure the occurrence of bias or not in research (Yin, 2009; Creswell, 2010; Wahyuni, 2012).

\section{RESULT AND DISCUSSION}

Village community should overcome many barriers to ensure the sustainability of village-owned enterprises. This study found some challenges in the village-owned enterprises in term of innovation. The challenges are: a) Lack of Knowledge and skills, b) Financial and infrastructure limitation, c) Social - professional conflict.

\subsection{Data Analysis}

\subsubsection{Lack of Knowledge and Skill}

Knowledge is important to the Village - owned enterprises' innovativeness as knowledge is fuel of the innovation. One of the most important factors for generating innovations is the knowledge basis of the workforce. The challenges on this term occur on the village-owned enterprises derives from two factors: a) low quality workforce, and b) Limited information access.

The quality of employees is a challenging issue for village - owned enterprises. The study found that the enterprises face many difficulties on finding the employees who have good competency and capabilities. Most of the young generations in the village which have adequate education level prefer to find a job outside the village. They choose to be an employee in the manufacturer company or move to the big city. This phenomenon explained by the director of SVO that said "We have problem on the human resources. It is difficult to get young talented employee. They prefer to be an employee in the company at the big city rather than working in the village."

Village - owned enterprises also have issue on the knowledge development because of the information access. The village-owned enterprise already familiar with the internet access, but the language has become a crucial factor for them. 
They eager develop their knowledge by searching the information on the internet, but the obstacle arises on the language. The Village - owned enterprises employee has insufficient English proficiency. This limitation according to them has significant impact on the knowledge development. They unable to capture the important information, such as new methods or new technologies, because the information was deliver in foreign language. This obstacle confirmed by PVO manager that said "I like to search information on the internet, but I cannot understand that information because it delivered in English."

Another problem in the issue of knowledge is the poor knowledge management of as Village-owned enterprises. The problem occurs because villageowned enterprises manager do not realize the importance of knowledge documentation. Tacit knowledge takes the most part of Village-owned enterprises'; hence they have difficulties to develop it. This condition explained by chief of Ponjong Village. He stated "As the village chief, I have responsibilities as commissioner of village-owned enterprises. In the beginning I did not know what I should do. There was no proper documentation that I can use to learn about this PVO. So I asked the former chief, then I learn by doing."

\subsubsection{Financial and Infrastructure Limitation}

Village - owned enterprises has limitation on financial resources. Government gives support in the beginning, but they need financial support for innovation. The Village-owned enterprises share their profit to some stakeholders such as village government and local community. This obligation reduces their ability to invest more on innovation. This condition explained by manager of BVO that said "We share the profit with the communities and also local stakeholders such as villagers by allocate the profit for development. Sometimes we have to make that allocation as a priority, hence we do not have sufficient fund for internal development and innovation." Manager of BVO confirmed this by his statement "We don't think about Research and Development division. We don't have fund allocation for R\&D."

Infrastructure also is an issue for Village-owned enterprises development. It needs to be improved. Village-owned enterprises also need to optimize their asset to gain the profit. They need to manage the assets and make improvement on it. This phenomenon explained by women community leader that said "Village-owned enterprises have some assets such as building and park, but they do not manage it very well. The roads need to be repair, the buildings need lighting. They do not optimize its function."

\subsubsection{Social-Professional Conflict}

Village-owned enterprises deal with social-professional conflict. This problem related to the human resources. Employees of the Village-owned enterprises have double job as a civil servant and also village-owned enterprises manager. Some of them also have another side job. This condition makes conflict in the managerial level. The employees do not focus on the development of Village-owned 
enterprises. This condition explained by employee of SVO who said "I also work as civil servant. My position in this enterprise based on my assignment from government."

Social-professional conflict also occurred in term of employee recruitment. Village-owned enterprises urge to recruit local people although they have limited capabilities. Local leader in the BVO village stated "Village-owned enterprises should give benefit to local people. So they should give priority to local people to be employees." Women community leader of PVO village also emphasis this condition by said "Even though local people education level is not high, they should get bigger chance to be an employee rather than outsider." Director of BVO also explained this condition. He said "We should recruit local people as employee. Sometimes we have difficulties to put them in the position because of their limited capabilities. We should conduct intensive training for them." This condition gives Village-owned enterprises obstacles for their development and also innovation.

In the other hand, Village-owned enterprises should be professional and fulfill their customer needs. Village-owned enterprises also serve local community as their customers which demand to be served professionally. Neighborhood chief in the SVO village explained this by said "We, as a customer, need good quality service. SVO needs to improve their quality of service. For example, the SVO should ensure the water flow day by day." From this statement, the study found that village-owned enterprises should overcome the social-professional conflict that arises in the village. They should accommodate social requisition to recruit local people who have low quality as employees, but they also should be professional to serve their customers.

\subsection{Discussion}

The study showed that human factor is the main challenge for village-owned enterprises. One of the most important factors for generating innovations is the knowledge basis of the workforce (Cabrera-Suarez, et al., 2001; Werner, et al., 2017; Chirico, 2008). Village-owned enterprises should solve this human factor challenge such as low quality employees, foreign language proficiency, and also young talented employee scarcity. These human factor obstacles drive the lack of knowledge and skills challenge for Village-owned enterprises innovation.

The challenge in term of knowledge and skills also occur when Village-owned enterprises do not pay attention on knowledge management. The knowledge that possess by Village-owned enterprises are majority in the form of tacit knowledge. Tacit knowledge has characteristic that difficult to be transferred and communicated (Jassimuddin et al., 2005). This condition make obstacle for Village-owned enterprises to use the knowledge. Another problem will occur if the person who has the knowledge resigns from the organization. The village-owned enterprises will lose that knowledge. Discontinuity of knowledge resources will hamper innovation development in the village-owned enterprises. 
Financial and infrastructure limitation also play significant role on innovation detention. This result is in line with the previous researches (e.g. Indarti and Langenberg, 2004). Fund is needed on the innovation development process. The scarcity of financial resources combines with the knowledge deficiency will drive the village-owned enterprise to the innovation myopia. The village-owned enterprises will not pay attention on innovation. Awareness to the importance of research and development in the village-owned enterprise would be stay at the low level.

Village-owned enterprises also have obstacle on social - professional conflict. This conflict will be an obstacle of innovation because the village-owned enterprises will have limitation to get good quality employees. The impact of this condition is the limitation of knowledge and skill of Village-owned enterprises and also their innovation capabilities.

\section{CONCLUSION}

The village-owned enterprises need innovation for their sustainability. This research found 3 major challenges for the village-owned enterprises innovation. The challenges are a) Lack of Knowledge and skills, b) Financial and infrastructure limitation, c) Social - professional conflict. Human factor is the main challenge that needs to be solved by village-owned enterprises. The village-owned enterprises should overcome these challenges hence they can be spared from Innovation myopia.

\subsection{Limitation and Future Research}

This research conducted in the village-owned enterprises which dominated by Javanese culture. This research also conducted in the service sector. In the future, exploring innovation challenge in the village-owned enterprise which has different culture would be interesting. The future research also can explore innovation challenge in the manufacturer village-owned enterprises.

\section{REFERENCE}

Barney, J., 1991, Firm Resources and Sustained Competitive Advantage. Journal of Management, 17(1), pp. 99-120.

Bachrein, 2010, Developing Village Approach in West Java: Rural Development Policy and Strategy, Analisa kebijakan pertanian, 8(2), pp. 133-149.

Behkish, M.M., 2002. Iran's Economy in the Context of Globalization. Ney Publication, Tehran.

Brines, S., Shepherd, D. \& Woods, C., 2013. SME family business innovation: exploring new combination. Journal of Family Business Management, 3(2), pp. 117-135. 
BPS DIY, 2013, Daerah Istimewa Yogyakarta dalam Angka 2013.

Creswell, J. W. (2010). Qualitative Inquiry and Research Design: Chosing Among Five Approach. University of Nebraska, Lincoln: SAGE Publication Ltd.

Chirico, F. 2008. Knowledge Accumulation in Family Firms : Evidence from Four Case Studies. International Small Business Journal, 26, pp. 433.

De Massis, A., et al., 2015, Product Innovation in Family versus Nonfamily Firms: an Exploratory Analysis. Journal of Small Bussiness Management, 53(1), pp. 1-36.

Heaton, J., 2005. Developing Entrepreneurs: An examination of systematic approaches to entrepreneurial development for rural areas. Illinois Institute for Rural Affairs, Rural Research Report.

Indarti, N., \& Langenberg, M. (2004). Factors affecting business success among SMEs:Empirical evidences from Indonesia. Second Bi-Annual European Summer University, Enschede, The Netherlands: University of Twente 19, pp. 1-14.

Jassimuddin S. M., Klein, J. H. and Con, C., 2005. The paradox using tacit and explicit knowledge: Strategies to face dilemma. Management Decision, 43(1), pp.102-112.

Llach, J., \& Nordqvist, M. (2010). Innovation In family and non-family business. International Journal Entrepreneurial Venturing, 2 Nos 3/4, pp. 381.

Langley, A. 1999. Strategies for theorizing from process data. Academy of Management Review. 4(24), pp. 691 - 710.

Markley, D.M., 2002. Entrepreneurship in Rural America: Prepared for the NCSL Rural Development Task Force. Center for Rural Entrepreneurship, Lincoln, Nebr.

Markley, D.M., 2005. Local Strategies for responding to rural restructuring: The role of entrepreneurship. Globalization and Restructuring in rural America, Conference ERS-USDA, Washington DC.

Mitchell, Ronald K., Bradley R. Agle, Donna J. Wood 1997, Toward a Theory of Stakeholder Identification and Salience: Defining the Principle of Who and What Really Counts, The Academy of Management Review, 22(4), pp. 853-886.

Nonaka, I., \& Takeuchi, H. 1995. The Knowledge-Creating Company. New York: Oxford University Press.

Prabowo, T.H.E., 2014, Developing Bumdes (Village-owned Enterprise) for Sustainable Poverty Alleviation Model Village Community Study in BleberanGunung Kidul-Indonesia. World Applied Sciences Journal 30 (Innovation Challenges in Multidiciplinary Research \& Practice), pp.19-26. 
Saunila, M., \& Ukko, J. 2014. Intangible aspects of Innovation Capabilities in SMEs: impacts of Size and Industry. Journal of Engineering Technological Management, 33(1), pp. 32-46.

Susetiawan. 2011. CSR: Komitmen untuk Pemberdayaan Masyarakat. DIY: Azzagrafika.

Trevinyo-Rodriguez, R. N., \& Tapies, J. 2006. Effective knowledge transfer in family firms. In P. Z. Poutziouris, K. X. Smyrnios, \& S. B. Klein, Handbook of research on family business. Celtenham, UK: Edwar Elgar Publishing Limited.

Wahyuni, S. 2012. Qualitative Research Method: Theory and Practice Volume 1. Jakarta: Penerbit Salemba Empat

Werner, A., Schroder, C., \& Chlosta, S. 2017. Driving Factors of Innovation in Family and Non-Fmaily SMEs. Small Business Economic, pp. 1-18.

Yin, R. K. 2009. Case Study Research. Thousand Oaks, California: Sage Publication, Inc. 